\title{
Measuring the Games Influence on Improving English Proficiency
}

\author{
Reni Dwi Pertiwi, Erdhi Widyarto N. \\ Department of Information System \\ Soegijapranata Catholic University, Semarang, Indonesia \\ reni2pertiwi@gmail.com
}

\begin{abstract}
English is now used as an international language, so that every person in order to communicate at the international level are required this language. To improving english proficiency, people used native speaker, course, story book, film game and etc. Games or better known as PC gaming is another alternative in improving the English proficiency. Beside this is fun, player required to read and listen the story game to finish the game. So that player can improve English proficiency while the player play game. In this paper, author present what game are fun and not boring also can improving English proficiency. The measuring improving English proficiency is observed from reading,writing, listening and grammar
\end{abstract}

Keyword: English, Game, improving,Proficiency.

\section{Introduction}

English is now used as an international language. The following is a list of territories where English is an official language, i.e., the language of government. In 2014, there were 58 sovereign states and 21 non-sovereign entities where English was an official language. Many country subdivisions have declared English the official language at the local or regional level.[1]

Beside that, Often education, research and common industry vocabulary is in English for these important careers. If is often required that people who study or work in these industries do research and learn about new and cutting edge ideas within in their industry in English. Many of the top industry publications and research is in English

But English language is not easy to learn. English is definitely one of the harder languages. English is a very well-known and well-heard language worldwide which most people hear quite frequently, but hearing it is not enough. Grammar is the most essential part to English, and the structure of it is so sporadic to the point where we can't explain a good deal of it properly because it's so random, and we take honors English classes. Not impossible, but if we want to learn proper grammar, be prepared for some brain freeze

There are many ways to learn eanglish language, example through native speaker ,courses, story book, film, game and etc.

Games could help encourage many learners in maintaining their interest.Although usually games just used as simple recreational activities, they are not that simple. They create a positive atmosphere while learning without thinking about learning. Well-chosen games give learners entertainment and at the same time allow them to practice their language skills[2] In this paper, author is discussing about how PC's game can improving English language. So that player can learn English language with relax and enjoy. So that player can learn English language and playing game

\section{Literature Review}

\subsection{Improving English language}

Speak as often and as much as possible! This is the best way to learn English! There is nothing better than conversation to help you improve. Whereas, we can practise reading, writing, and listening on your own, it's obviously better to speak English with someone. The best way to do this is to be in an 
English speaking environment. Take an English course in an English language school, or better still, learn English in an Englishspeaking country.

The quickest way to learn English is to surround yourself with English speakers. Also, get into the habit of thinking in English, don't translate from your own language into English, it will slow you down. When you talk, use the sentences which instantly and naturally feel right to you, these are often the correct ones. Many students learn to develop an 'intuition' about English, use yours and trust it.

This might sound a little strange and embarrassing at first, but record yourself talking and listen to your own pronunciation, talking speed and the flow of your speaking. It will give you a great chance to see the areas you need to work on.

\subsubsection{Listening}

This really is a skill that needs to be worked on everyday. Like speaking, it's better for you to be in a totally English speaking environment. Full immersion is the best way for you to improve your level. Again, nothing can beat learning at an English language school abroad.

\subsubsection{Reading}

Reading English is something they can do to help you learn on your own, outside of the classroom. Have a dictionary with you (English/English is best.) to look up new words and then write them down in a notebook. Try to use these new words in conversation,it's a great way to learn.

\subsubsection{Writing}

Try keeping a diary; write something in English in it every day, even if it's very simple. Start with small sentences and make them longer. Again, the internet is a great way to help. Try to make friends online, visit chat rooms, forums, or post comments on blogs.
These are all useful tools for you to learn well from.

Writing gives they a good chance to review words you have learned in the past, and allows you the time to think about grammar as you write. Go back and review anything you might have written in the past,when your English was at a lower level, and try to find any mistakes you made.[3]

\subsection{Game Genres}

Like cinema, computer games have as many different genre categories as they do audience groups. Unlike cinema, many of them are known by their tongue-twisting acronyms! Here are some of the most notable:

Adventure: Adventure games involve exploration of, and interaction with, the environment as a main facet of gameplay. Story and puzzle solving are also highlighted and interaction is usually driven by point and click. Fighting plays a minor role. Adventure games include Zork and Myst.

Classic Arcade: Classic arcade games refer to games that originally existed on freestanding coin-operated machines. Classic arcade games include Pong and Space Invaders

Fighting: Fighting games involves rendering opponents unconscious or dead by using a number of different moves. Gameplay tactics are limited to selecting the most appropriate move in a situation. Fighting games include Tekken 3 and Street Fighter.

First Person Shooters (or FPS): are games in which the player has a first-person perspective of their character. FPS shooters include Doom and Quake

First Person Sneaker: This is a sub-genre of First Person Shooter, where the focus is on stealth rather than combat or shooting.

MMORPG: 'Massively Multiplayer Online Role Playing Games' are multi-player role-playing games that enable thousands of players to play in an evolving virtual online 
world at the same time. MMORPGs include Diablo and WarCraft

MOO: 'Multi-User Domain - Object Oriented' is a type of MUD that allows players greater freedom such as creating new objects and character descriptions and programming new verbs.

MUD: 'Multi User Dimension' (or 'Multi User Dungeon' or 'Multi-User Domain') is a text-based, game-world on the internet where the players can interact using text commands. Generally RPG games.

Platform: Platformers or side scrollers are games in which the background scrolls and the player jumps from platform to platform. Game-play generally includes running and jumping. Platform games include Donkey King and Super Mario Bros.

Racing Games: Racing games involve the player competing in races. Racing games include Daytona and the Mario Kart series.

RPG: 'Role Playing Games' are games in which the player's character has skills and abilities represented by statistics. Gameplay involves the characters exploring and completing quests that build up their statistics and possessions. Can be single or multi-player. RPGs include Everquest and Ultima

Shooters: Shoot em' Up or Shooter games involve shooting or destroying multiple objects and opponents. Shoot 'em up games include Doom and Asteroids.

Strategy Games: Strategy games require the player to take on a leadership role and oversee every detail of the provided scenario(s). Gameplay focuses on strategies and careful planning and resource management in order to win. Strategy games include Age of Mythology.

RTS: 'Real Time Strategy' games are strategy games played in real time. RTS include Command and Conquer and Rise of Nations.

Serious Games: Serious games are games aimed at teaching, discussing or debating real- world concepts via gameplay. Serious games include Virtual U.

Simulations: Simulation games attempt to realistically mimic conditions of a particular environment or activity. Sim games include SimCity and Flight emulators.

Sports Games: Sports Games emulate traditional physical sports such as basketball and golf.

\section{Method}

On this paper, author compare 8 game that have genre RPG,RTS and action game. To compare this game, author based on how this game can improve English proficiency. To measure English proficiency, like:[4]

- Reading

- Writing

- Listening

- Grammar (optional)

- Game fun

Games that compare are

- Battle tech

- Dungeons \& Dragons

- Civilization V : Gods and Kings

- Age of Empires III

- Bubble

- Big describer

- Sentence monkey

- Connector matching game

\section{Result and Discussion}

Battle tech, In this science fiction roleplaying game(RPG), they play the role of a soldier, or perhaps a mercenary, traveling from planet to planet, and fighting in a 10-meter tall war machine, either for money or glory. Perhaps they are helping rebel soldiers to overthrow a tyrant. Or perhaps they are working for that tyrant to put down a rebellion.

In this game, players must follow many conversations on the story game, but just beside reading and choosing This game also require players to fight and solve problems so 
the players would not become bored and the player can improve skill English language

Dungeons \& Dragons also genre RPG game, the bard characters are usually portrayed as happy-go-lucky traveling poets and singers. Bard players often make up lyrics and sing to the tune of popular songs during the game.The fighters are often portrayed as simple-minded muscle heads, but that's just a stereotype. The player can of course also role-play a fighter in a different way.The mages or magicians are just the opposite; they are often portrayed as cautious and intelligent powermongers

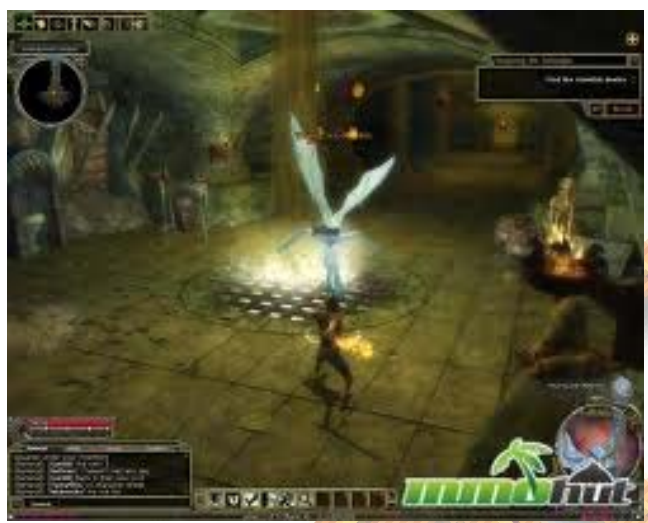

Fig.1 Game Dungeons \& Dragons

Same as the battle tech, this game require players follow many conversation, so that the player can improve skill English language on reading and listening. While this game does not to improve writing skill.

Civilization V :Gods and Kings came out in 2012. The Genre game is real time Strategy. The release date, as with some others in this list, has not prevented the turn based epic strategy from retaining a high position of popularity and long term prosperity in the genre. In civilization payer have an amazing amount of customization options in starting the game.

Same as the battle tech, this game require players follow many conversation, so that the player can improve skill English language on reading and listening. Beside that player does not required to follow story line on this game.
So that player can play this game without understand the story line if the player understand the story line with listen and read son this game, then the game better to be fun.

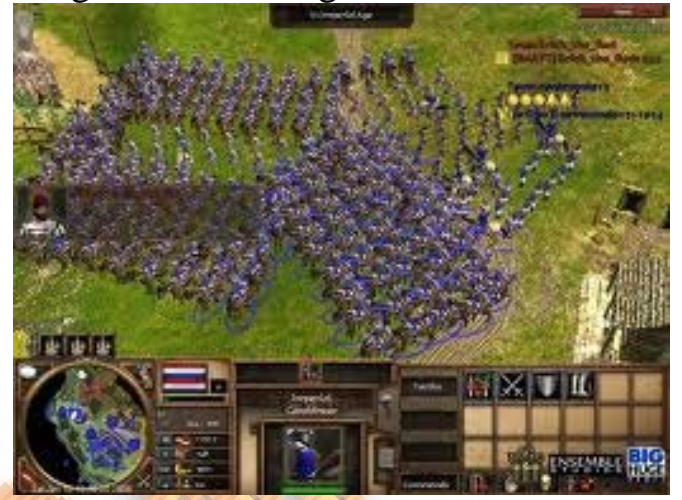

Fig.2 Age of empire III

Age of Empires III focuses on the many European powers vying for power over the New World. This game also RTS'game.This revolves around there civilization and how well they can build both there economy and military might. The game includes eight different civilizations with the ability to utilize other civilizations in the form of mercenaries. The eight civilizations include the British, French, Spanish, Dutch, Russians, Portuguese, Germans, Ottomans

This game like civilization. So that this Game more to be fun if player can reading and listening the story line.

Sentence monkey and Connector matching game can accessed on http://www.eslgamesplus.com/. On this address, we can meet other game despite Sentence monkey and Connector matching game.

Sentence monkey are activity helps students practice sentences and grammatical structures in a fun way. Students drag and drop words to finish and form correct grammatical sentences

Connector games are great matching games for ESL vocabulary practice. They are excellent for comparing and contrasting vocabulary. They will find antonyms and 
synonyms adjectives and verbs vocabulary building activities

Bubble and Big describer can play through gamestolearnenglish.com. on bubble, they practice grammar and word order. Click the bubbles and construct sentences to review English grammar. Big describer, read the description and click on the matching image. Practice English vocabulary and reading with this game.

If at the table to back it can be concluded as follows

\begin{tabular}{|c|c|c|c|c|c|}
\hline & $\begin{array}{l}\text { Listeni } \\
\text { ng }\end{array}$ & $\begin{array}{l}\text { Writin } \\
\mathrm{g}\end{array}$ & $\begin{array}{l}\text { Readi } \\
\text { ng }\end{array}$ & $\begin{array}{l}\text { gramat } \\
\text { ical }\end{array}$ & $\begin{array}{l}\text { Game } \\
\text { fun }\end{array}$ \\
\hline $\begin{array}{l}\text { Battle } \\
\text { tech }\end{array}$ & $\begin{array}{l}\text { Very } \\
\text { good }\end{array}$ & Bad & $\begin{array}{l}\text { Very } \\
\text { good }\end{array}$ & Good & $\begin{array}{l}\text { Very } \\
\text { good }\end{array}$ \\
\hline $\begin{array}{l}\text { Dungeon } \\
\text { S \& \& } \\
\text { Dragons }\end{array}$ & $\begin{array}{l}\text { Very } \\
\text { good }\end{array}$ & Bad & $\begin{array}{l}\text { Very } \\
\text { good }\end{array}$ & Good & $\begin{array}{l}\text { Very } \\
\text { good }\end{array}$ \\
\hline $\begin{array}{l}\text { Civilizati } \\
\text { on }\end{array}$ & Good & Bad & Good & Good & $\begin{array}{l}\text { Very } \\
\text { good }\end{array}$ \\
\hline $\begin{array}{l}\text { Age of } \\
\text { empire } \\
\text { III }\end{array}$ & Good & Bad & Good & Good & $\begin{array}{l}\text { Very } \\
\text { good }\end{array}$ \\
\hline $\begin{array}{l}\text { Sentence } \\
\text { monkey }\end{array}$ & Good & Good & $\begin{array}{l}\text { Very } \\
\text { good }\end{array}$ & $\begin{array}{l}\text { Very } \\
\text { good }\end{array}$ & Fair \\
\hline $\begin{array}{l}\text { Connecto } \\
\text { r game }\end{array}$ & good & Good & Good & Good & Fair \\
\hline Bubble & good & Good & Good & Good & Fair \\
\hline $\begin{array}{l}\text { Big } \\
\text { describer }\end{array}$ & good & Good & Good & Good & \\
\hline
\end{tabular}

Table 1 Table Game Compared

\section{Conclusion}

Pc Games can improve English language proficiency. player can learn the game to be more fun and improved the English language proficiency.

Game have genre RPG (Battle tech Dungeons \& Dragons) and RTS(Civilization Age of empire III) more to be fun than arcade game or action game, beside that RPG game required to understand the story line if the player want to finish this game, while RTS game, if player understand this game, the player more to be fun.
Games arcade like bubble sentence monkey good to improve English proficiency but this game seem boring and not fun

\section{Daftar Pustaka}

[1]http://en.wikipedia.org/wiki/List_of_countri es_where_English_is_an_official_language List of countries where English is an official language 16 July 2013

[2] Andrew Wright, David Betteridge and Michael Buckby. Games for Language Learning. Cambridge University Press. 1984

[3] http://www.wikihow.com/Improve-YourEnglish,

[4] Maritza Maribel Martínez Sánchez,Armando Pérez Morfín, and Vilma E. Portillo Campos. Interactive games in the teaching-learning process of a foreign language. Teoría y Praxis. 2007 